\title{
The constructivist approach (coap) to enhance students comprehension in reading procedure text for students of Universitas Muhammadiyah Sidenreng Rappang
}

\author{
Hardianti $^{\mathrm{a}, 1, *}$, Jamaluddin Ahmad ${ }^{\mathrm{b}, 2}$, Syam Hermansyah ${ }^{\mathrm{c}, 3}$ \\ a, b, c Universitas Muhammadiyah Sidenreng Rappang, Maccorawalie, Panca Rijang, Kabupaten Sidenreng Rappang, Sulawesi Selatan 91651, Indonesia \\ ${ }^{1}$ hardianti_43122110@yahoo.co.id *; ${ }^{2}$ jahmadlado@yahoo.co.id ; ${ }^{3}$ syamhermansyah@gmail.com \\ * corresponding author
}

ARTICLE INFO

Article history

Received 6 December 2019

Revised 14 March 2020

Accepted 17 August 2020

Available Online 15 January 2021

Keywords

constructivist approach

reading comprehension

procedure text

\section{ABSTRACT}

This research aimed to investigate the constructivist approach to enhance students reading comprehension at UMS Rappang. This research employed the pre-experimental method with one group pre-test and post-test design. The population was the second-year students of UMS Rappang in 2018-2019 academic years. The population included 66 students consisting of three classes; one class (I.2) was taken as a sample by using cluster sampling, as many as 22 students. The instrument used in this research was reading test. The result of this research showed that the pre-test got the mean score of 44.50 , while the post-test 64.18 . It showed that the p-value $(0.000)$ was lower than the level of significance (alpha $(\alpha)=0.05)$. It means that H1 was accepted. The research concluded that teaching reading comprehension by using a constructivist approach enhances students' reading comprehension at the First year of UMS Rappang.

This is an open access article under the CC-BY-SA license.

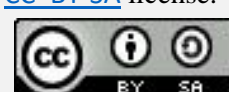

\section{Introduction}

Reading is an intricate cognitive process of making sense symbols to construct or obtain meaning (understanding reading). It is a way of obtaining language, communication, and sharing information and ideas. Like all languages, this is a complicated conversation between the text and the reader compiled by the previous knowledge, experience, attitude, and community of readers provided by culture and society. Reading process requires practice, development, and improvement.

Constructivism is the result of 'mental construction' where students build their understanding by reflecting on their personal experiences, and by connecting new knowledge with what they already know. Each student makes his 'change' or mental model for understanding the world and accommodate new knowledge (learning) by adjusting it. One of the principles that support learning is to look for meaning; therefore, to be effective, a teacher must help students find their meaning.

\subsection{Problem Statement}

Based on the background of the problem, then could be formulated in this study as follow:

"Does the constructivist approach enhance students reading comprehension at UMS Rappang?"

\subsection{Objective of the Research}

The present study was aimed to investigate the effectiveness of the constructivist approach in enhancing students' reading comprehension at UMS Rappang. The results of this study are expected to be useful information for students, teachers, and researchers. 
1) For English teachers, it can be an alternative learning material in teaching English, especially reading comprehension.

2) For students, the research is expected to help students comprehend reading text through a constructivist approach.

3) For other researchers, the research provides useful references in further studies about teaching reading comprehension using a constructivist approach.

\subsection{Scope of the Research}

The scope of this research was divided by discipline, content, and activity.

1) By discipline, this researcher is delimited to applied linguistics discussing the teaching subjects in terms of reading comprehension.

2) By content, the present study focused on the genre listed in KTSP curriculum, which is reading, following the minimum standard criteria 7.0. In particular, it is to comprehend short functional text and simple essay of everyday life. The essential competencies included responding to meaning and rhetoric steps in simple essay accurately, fluently in context procedure text.

3) By activity, the research explains about reading comprehension using the constructivist approach learning model and the researcher gives some topics about reading comprehension to the students. they are how to make fried rice, how to charge handphone battery, how to make a kite, and how to boil an egg in a simple and easy way.

\subsection{Review of Related Literature}

Reading is when someone investigates a written text and starts to absorb information from the written linguistic message. Reading is beneficial for language acquisition process. Regarding reading activity among learners, the more they read, the better they comprehend it (Harmer, 2007: 99). Reading is a process of constant guessing, and what someone brings to the next is often more important than what someone finds in it (Grellet, 2004: 7). Reading activity should introduce students to implement what they know or have learnt to understand the unidentified elements, such as simple ideas or words.

Based on the definition above, the researcher concludes that reading is the process of understanding words, ideas or ideas and taking meaning and managing it based on what they have read.

\subsection{The Concept of Constructivist Approach}

Constructivism is an epistemology employed to describe that people know what they know. Ideas are problem solving, thinking, and development. When people solve problems and find ways to solve them - by reflecting on past and direct experiences - they build their understanding. Thus, learning is an active process requiring a change from the learners. The change is achieved through activities carried out by students, such as from the results of these activities, and through reflection. People only comprehend what they have built.

One way to organize constructivist views is talking about three forms of constructivism: psychological/individual/endogenous constructivism, social/exogenous constructivism, and dialectical constructivism (Palincsar, 1998; Phillips, 1995). We can oversimplify it by saying that psychological constructivism focuses on how information, resources, and help from others are used by individuals to build and improve the mental model and problem-solving strategy. Conversely, social/exogenous constructivism view of learning is an increased ability to participate with others in meaningful activities within the culture (Woolfolk, 2009; Windschit, 2002). Whereas dialectical constructivism is a combination of psychological/individual/endogenous and social/exogenous.

To sum up, constructivism provides human with activities to help them figure out their capability, knowledge, technology, and other significant things to develop themselves.

\subsection{Constructivist Theories of Learning}

Constructivism is a scientific study on the learning mechanisms of human beings. Constructivism believes that people build an understanding of the world through things and these are reflected on those experiences (Bereiter, 1994). When we find something new, we must reconcile it with our 
previous ideas and experiences. We might change what we believe in, or we might move new information that is not relevant. However, we are active creators of our knowledge. To be able to do this, we must ask questions, discuss, and assess what we ask. In the classroom, constructivist views about learning can be used in different lessons. In the most common sense, it usually that encourages students to use active techniques (experiments, solving real-world problems) to create more knowledge and then to reflect and talk about what they do and understand the change.

Another point to discuss is that learning is an active concept rather than the passive one. Learners obtain their understanding of what they encounter in new learning. If they did not understand the situation, they can improve it and prepare themselves for the new experiences. This way, students remain active throughout the learning process. Current understanding, noting the relevant ones in the new learning experience, and assessing the consistency of previous knowledge and those that arise, and according to what they get, can help them compare knowledge (Phillips, 1995).

\subsection{Previous Related Findings}

Previous studies about the topic have been conducted. For example, Gilakjani (2016) mentioned that reading is an interactive process since readers construct meaningful representations of texts using effective reading strategies. They are deemed essential centering on the students' comprehension and detailed reading skills. The finding indicates that reading strategies play a significant role in improving students' reading comprehension.

Aliponga (2013) mentioned several factors to consider for a successful extensive reading. The findings investigate the benefits of extensive reading, revealing that it motivated students to read more, allow them to understand the main ideas and the essential details, and enable them to think critically.

Therefore, the use of constructivist approaches can improve students in reading comprehension. In short, it is necessary to increase the students' reading comprehension skills. Teachers must find out the appropriate approach to make the learning interactive.

\subsection{Hypothesis}

In accordance with the conceptual framework, the researcher writes down two hypotheses as the followings.

1) Null Hypothesis $\left(\mathrm{H}_{0}\right)$ : Constructivist Approach (COAP) is not significant in reading comprehension.

2) Alternative Hypothesis $\left(\mathrm{H}_{\mathrm{a}}\right)$ : Constructivist Approach (COAP) is significant in reading comprehension

\section{Research Method}

Among the extensive research, experiments are divided into three types, namely: Pre-experiment Design, True Experiment, Quasi-Experimental Design and Factorial Design. Where alternative designs in pre-experimental use divided into three, namely: one-time case study, one pretest-posttest design group and static-group comparison, in this study the researchers used pre-experiment with one-group pretest-posttest design (Gay, 2006: 251).

The present study used pre-test experimental with one group pre-test, treatment and post-test design to know the student's ability in reading comprehension. Experiments are one of the most widely applied research methods in all fields of science. Pre-experimental is a design that is not a real experiment - really because it has outside variables that are the influence of the dependent variables (Sugiyono, 2017: 74). The main characteristics of experimental research are the treatment conducted by researchers on the subject of research.

\subsection{Variable of the Research}

Variable is something that became the object of observation research, often also referred to as factors that play a role in research or symptoms to be studied. According to Kerliger in Sugiyono (2017: 39), variable is the constructs or properties to be learned. In another section, Kerliger states that it is properties that take from of a different value. According to Sugiyono (2017: 38), the 
research variable is everything in the form of what is determined by the researcher to study so that information obtained about it, then the conclusions are drawn.

There are two variables in this study, namely independent $(\mathrm{X})$ and dependent $(\mathrm{Y})$. The independent variable is the constructivist approach $(\mathrm{X})$, and the dependent variable is the students reading comprehension achievement $(\mathrm{Y})$.

The paradigm design of the variables revealed in Figure 1 below:

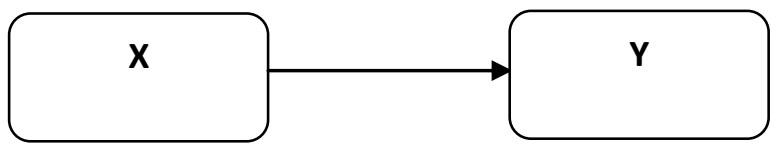

Fig. 1. Variable Design

(Sugiyono, 2017:42)

Where:

$\mathrm{X}$ : The constructivist approach

Y: Students reading comprehension achievement

The present study investigated the university students' current discussion about the purpose of reading and learning. In general, the study tried to explain the phenomenon through the students' attitudes, activities, and skills. In the present study, teachers were trained in complete harmonized courses about academic readings. Selected classroom activities encouraged students to use highlevel thinking to build meaning from academic text, while teachers use tools to discuss the questions raised by the students.

1) Reading comprehension is the process of making sense or meaning from text. The aim of this process is to get a thorough understanding of what is explained in the text instead of getting meaning from isolated words or sentences.

2) The Constructivist Approach is one approach that also discusses other forms of psychotherapy, namely (i) cognitive therapy, an action-oriented form of therapy encouraging clients who change maladaptive thought patterns leading to maladaptive and harmful influences, and (ii) psychoanalysis, a branch of mind psychotherapy conscious and unconscious.

\subsection{Population and Sample}

The population of this research is the first semester students at UMS Rappang. It consists of three classes in which the sum number are 66 students. The research employed cluster sampling (area sampling) method to determine the sample, which is based on a predetermined population. The firstyear students, as many as 22 students, of UMS Rappang were chosen as the sample.

\subsection{Instrument of the Research}

The research employed a test as the instrument in collecting the data. It is given in the pre-test and post-test in the form of multiple choice, true/false, and filling in the blanks. The pre-test was aimed to find out the prior knowledge of the students in reading comprehension before treatment. Moreover, the post-test is aimed to find out the students' reading comprehension after the treatment using the constructivist approach. The topics presented in the approach included how to make fried rice, how to charge handphone battery, how to make a kite, and how to boil an egg.

\subsection{Procedure of Collecting Data}

The research procedure includes these steps:

1) Pre-test was given prior to treatment in the first meeting. The procedure of the test is as the following.

a) The researcher explained what the students were going to do and distributed the text for the class to investigate the students' ability in reading comprehension test.

b) The researcher shared the score of the students' test.

2) Post-test

a) After given the treatment, the researcher has given students an understanding of the activity and asks for their suggestions and comments about the learning process.

b) The researcher has given a score on the student test results in their. 


\subsection{Treatment}

The researcher has given treatment to the group. There are four meetings as the treatments. Each meeting lasted for 80 minutes. The researcher uses the Constructivist Approach. The treatment procedure is as follows.

1) Students were given information about the activities, while teachers (researchers) prepared the text. The students were divided into small groups.

2) Students were given time for group discussion.

3) Students were given indicator questions related to the topics assigned to them

4) Students were given five minutes to exchange questions with other groups.

5) Each member must answer the questions given. If other members answered the questions for a member, they can be dismissed from answering the questions.

6) The teacher controls the exchange, so this will be a more appropriate way to measure into learning, and then Ask the last question for students to find more from the core

After given treatment, the researcher gave students an understanding of the activities and asks for their suggestions and comments about the learning process. Then the researchers reexamine the knowledge they have obtained during the four meetings with treatment through a post-test to measure students reading comprehension achievement.

\subsection{Technique of Data Analysis}

The data obtained from the tests were analyzed using descriptive statistic techniques. The tests consisted of multiple-choice, true/false, and filling in the blanks.

\section{Findings and Discussion}

This section discusses findings presented from descriptive statistics and interpretation of group test results. The pre-test and post-tests showed significant difference of the students' reading comprehension.

After the treatment using the constructivist approach techniques, the students' reading ability increased. It was evident in the mean score of the post-test, which was 64,18 . The score was higher than the mean score of the pre-test, which was 44.5.

Further, based on student learning outcomes obtained and stated in the above findings, researchers used t-test in inferential statistics through SPSS program version 21.0 to test the hypothesis. The result of the statistical test shows that P-value is lower than alpha $(\alpha)$ value $(0.000$ $<0,005)$, meaning the null hypothesis rejected, and the alternative hypothesis is accepted. That means $\mathrm{H} 1$ is accepted and $\mathrm{H} 0$ is rejected. It concludes that there was a significant increase among students in reading comprehension. In other words, there is an increase in students' reading comprehension after applying a constructivist approach at SMP Negeri 1 Baranti.

Olusegun (2015) in his article "Constructivism Learning Theory: A paradigm for teaching and learning" mentioned that constructivism represents one of the big ideas in education. The implication for teachers is great. If we strive in reforming education for all students, we must focus on students. To date, student-centered learning is perhaps the most important consideration for constructivism. The article discussed the constructivism theory to support teaching and learning process. Constructivism is a learning theory found in psychology. It explains how people can acquire knowledge. In short., the theory has direct implication on education.

Constructivism is the result of 'mental construction' - students build their understanding by reflecting on their personal experiences, and by connecting new knowledge with what they already know. Each student makes his 'change' or mental model for understanding the world, and accommodate new knowledge (learning) by adjusting it. One of the principles that support learning is to look for meaning; therefore, to be effective, a teacher must help students find their meaning. 


\section{Conclusion}

The results of the analysis show that teaching reading comprehension in English through a constructivist approach to First-grade students of UMS Rappang was sufficient. The result of hypothesis testing shows that $p$-value was lower than alpha $(\alpha)$ value $(0,000<0.005)$, it means the alternative hypothesis is accepted. On the other hand, the null hypothesis $\left(\mathrm{H}_{0}\right)$ is rejected.

\subsection{Suggestion}

Based on the conclusion, the present study suggested the followings.

1) English teachers should apply various teaching techniques and learning strategies. It allows them to feel comfortable to improve their reading comprehension. One of the many teaching aspects that can be improved in reading comprehension is by using constructivist approach.

2) It is advisable for students to use the constructivist approach as it can improve their reading comprehension skills and motivate them to learn English.

3) It is suggested that further research investigate the use of various reading texts in the teaching, treated as reference and guidance to obtain a more comprehensive result.

\section{References}

Aliponga, J. (2013). Its benefits for extensive reading. International journal of humanities and social science, 3 (12). Japan: University of International Studies Shioe.

Bereiter, C. (1994). Constructivism, socioculturalism, and Popper's world 3. Educational Researcher, 23 (7), 21--23.

Gay, L. R., et al. (2006). Educational research competencies for analysis and applications: Eight edition. Columbus Ohio. Pearson Merril Prentice Hall.

Gilakjani, A. P. (2016). How can students improve their reading comprehension skill? Journal of Studies in Education, ISSN 2162-6952, 6 (2). Iran: Department of English Language Translation Islamic Azad University, Lahijan Branch, Lahijan.

Grellet. (2004). Developing reading skills. Sydney: Cambridge university press.

Harmer, J. (2007). The practice of English Language Teaching. Harlow: Longman

Olusegun, S. (2015). Constructivism learning theory: A paradigm for teaching and learning. IOSR Journal of Research \& Method in Education (IOSR-JRME), 5, 66-70.

Palincsar, A. S. (1998). Social constructivist perspectives on teaching and learning. Annual Review of Psychology, 49, 345-375. https://doi.org/10.1146/annurev.psych.49.1.345

Phillips, D. C. (1995). The good, the bad, and the ugly: The many faces of constructivism. Educational Researcher, 24 (7), 5 - 12.

Sugiyono. (2017). Metode penelitian kuantitatif, kualitatif, dan $R \& D$. Bandung: Alfabeta.

Windschitl, M. (2002). Framing constructivism in practice as the negotiation of dilemmas: An analysis of the conceptual, pedagogical, cultural, and political challenges facing teachers. Review of Educational Research, 72(2), 131-175.

Woolfolk, A. (2009). Educational psychology active learning edition. Translated by: Helly Prajitno Soetjipto. Boston: Pearson Education, Inc., Publishing. 